\title{
Community-based Project Module: A service-learning module for the Faculty of Engineering, Built Environment and Information Technology at the University of Pretoria
}

\author{
M. Jordaan \\ Faculty of Engineering, Built Environment and Information Technology \\ University of Pretoria \\ South Africa \\ martina@up.ac.za
}

\begin{abstract}
In 2005, the Faculty of Engineering, Built Environment and Information Technology (EBIT) at the University of Pretoria, implemented a compulsory module, the Community-based Project Module, for all its undergraduate students. The module is an eight-credit module ( 80 hours) that is offered on an open-ended and projectorientated basis. A large number of students are registered $( \pm 1600$ students per year) and work on more than 590 projects, with more than 400 community partners annually. The module requires students to work in the community for at least $\mathbf{4 0}$ hours, during which time they address a specific need in the community. They subsequently have to complete various assignments where they reflect on their experiences. Popular student projects include teaching Mathematics and Physical Sciences at secondary schools, doing renovation projects, repairing old computers for schools and non-profit organisations, and teaching basic computer skills to community members.
\end{abstract}

Index terms - community engagement; service learning; South Africa; University of Pretoria

\section{BACKGROUND}

The University of Pretoria is one of 11 government-funded non-profit higher education entities in South Africa, with 48757 contact students comprising 34466 undergraduate and 14291 postgraduate students, as well as 16441 distance education students. ${ }^{i}$ More than half (52.2\%) of the enrolments are in the fields of science, engineering and technology. ${ }^{\mathrm{ii}}$ The Faculty of Engineering, Built Environment and Information Technology (EBIT) includes nine different disciplines for engineering, five disciplines for information technology, six disciplines for the built environment, the Graduate School of Technology Management, as well as various research institutes and centres. ${ }^{\text {iii }}$

In 2005, after approval from the University of Pretoria's Senate, the Faculty implemented a separate compulsory module (subject), the Community-based Project Module, for all undergraduate students enrolled in the Faculty. This type of module was the first of its kind in South Africa and a new endeavour for the Faculty. The Community-based Project Module is an eight-credit module ( 80 hours) that is offered on an open-ended and projectorientated basis. Students have to work in the community for 40 hours and then reflect on their experiences through different assignments. ${ }^{\text {iv }}$

Since service learning was not included in the Faculty's curriculum of existing modules, the establishment of a new, separate module was necessary to centralise and coordinate community service initiatives. The main reason for creating a separate module was to accommodate the large number of students annually enrolled in the Faculty. Logistically, it would have been complicated to add a service-learning strand to the curriculum of each existing course. One of the complicating factors was the design and 
development of a module that would consider the demanding curricula and time schedules of students in the Faculty.

Students may enrol for the Community-based Project Module as of their second year. However, some entities in the Faculty, such as the Department of Construction Economics, included the Community-based Project Module in the curriculum of its third-year students.

\section{INTRODUCTION}

The main objectives of the module are that the community project must aim to benefit a chosen section of society, while exposing engineering students to real-life issues. By involving the students in the communities, they have the opportunity to become more aware of their responsibility to the community as a whole, their citizenship and how they can utilise their acquired knowledge to enhance the community's wellbeing. It is recommended that students identify a project in a section of society that is different from their own social background.

While executing the project, students have to develop a sense of social responsibility, an understanding of social issues and an awareness of personal, social and cultural values. It is also important that students develop multidisciplinary life skills, such as communication, interpersonal and leadership skills. The project's learning outcomes depend on the nature of the chosen project. Students have to be able to work effectively in a multidisciplinary environment, perform critical functions and communicate effectively with the community members concerned.

The University of Pretoria's branding is linked to the students' involvement in communities. A successful project in a community not only contributes to the module's sustainability, but also to the University of Pretoria's continuous involvement in the community. ${ }^{\mathrm{V}}$ In 2014, the Community-based Project Module received a national award from Marketing, Advancement and Communication in Education (MACE) in the category for integrated campaigns or projects and subcategory: Social Responsibility Citizenship Development $^{\mathrm{vi}}$ for its successful use of the University of Pretoria's branding and marketing.

\section{NUMBER OF STUDENTS ENROLLED FOR THE COMMUNITY-BASED PROJECT MODULE AND PROJECTS IN THE MODULE}

The Community-based Project Module was launched as a pilot module in 2005. In 2009, the module became compulsory for all undergraduate students in the EBIT Faculty. The increase in the number of students in the module correlates with the increase in the number of students enrolled in the Faculty. One lecturer and one administration staff member are allocated to the module.

The number of students enrolled in the module has continued to grow since 2005 , as shown in Table 1. 
TABLE 1

NUMBER OF STUDENTS ENROLLED IN THE COMMUNITY-BASED PROJECT

MODULE

\begin{tabular}{|l|c|c|c|c|c|c|c|c|c|c|}
\hline & $\mathbf{2 0 0 5}$ & $\mathbf{2 0 0 6}$ & $\mathbf{2 0 0 7}$ & $\mathbf{2 0 0 8}$ & $\mathbf{2 0 0 9}$ & $\mathbf{2 0 1 0}$ & $\mathbf{2 0 1 1}$ & $\mathbf{2 0 1 2}$ & $\mathbf{2 0 1 3}$ & $\mathbf{2 0 1 4}$ \\
\hline $\begin{array}{l}\text { School for } \\
\text { the Built } \\
\text { Environment }\end{array}$ & 103 & 156 & 250 & 226 & 249 & 238 & 264 & 265 & 269 & 227 \\
\hline $\begin{array}{l}\text { School of } \\
\text { Information } \\
\text { Technology }\end{array}$ & 14 & 165 & 218 & 258 & 231 & 303 & 367 & 330 & 377 & 320 \\
\hline $\begin{array}{l}\text { School of } \\
\text { Engineering }\end{array}$ & 121 & 417 & 742 & $1213^{*}$ & $815^{*}$ & 918 & 959 & 1003 & 1001 & 1140 \\
\hline TOTAL & 238 & 738 & 1210 & 1697 & 1295 & 1459 & 1590 & 1590 & 1647 & 1687 \\
\hline
\end{tabular}

*Students initially had the option of choosing between two modules. From 2009, this choice has not been available, hence the lower enrolment figures.

TABLE 2

NUMBER OF PROJECTS AND COMMUNITY PARTNERS FOR THE MODULE

\begin{tabular}{|l|c|c|c|c|c|c|c|c|c|c|}
\hline & $\mathbf{2 0 0 5}$ & $\mathbf{2 0 0 6}$ & $\mathbf{2 0 0 7}$ & $\mathbf{2 0 0 8}$ & $\mathbf{2 0 0 9}$ & $\mathbf{2 0 1 0}$ & $\mathbf{2 0 1 1}$ & $\mathbf{2 0 1 2}$ & $\mathbf{2 0 1 3}$ & $\mathbf{2 0 1 4}$ \\
\hline $\begin{array}{l}\text { Number of } \\
\text { projects }\end{array}$ & 47 & 244 & 345 & 482 & 445 & 432 & 523 & 512 & 574 & 556 \\
\hline $\begin{array}{l}\text { Number of } \\
\text { community } \\
\text { partners }\end{array}$ & 31 & 186 & 267 & 381 & 288 & 265 & 398 & 421 & 401 & 394 \\
\hline
\end{tabular}

As can be expected, the number of projects increased as the number of students increased. Campus-community partnerships are also flexible, as students may work in a community for only one year and the campus-community partnership may, therefore, not continue in the following year. Many of the campus-community partnerships that were created when the Community-based Project Module was initiated are, however, still maintained.

\section{THE BLENDED LEARNING STRUCTURE OF THE COMMUNITY-BASED PROJECT MODULE}

Due to the large number of students involved ( \pm 1600 students per year) and only one lecturer and one administration clerk allocated to the module, it was necessary to develop a blended learning approach to support the instructor-led training. The large number of students requires the lecturer to depend on the Learning Management System (LMS) in use at the University of Pretoria (Blackboard ${ }^{\mathrm{TM}}$ ) to facilitate the module. The module is delivered predominantly electronically with limited traditional face-to-face lectures. The LMS is used for sharing important learning materials, online assessment and the administrative coordination of the module. The lecturer uses the LMS to facilitate effective communication with the students. Important information is frequently shared with the students via the announcement tool. Relevant information about the module is also shared via the LMS. Students are able to submit their assignments and schedule their project proposals and presentation sessions. They are required to book a project proposal session with the lecturer, which may be done on the LMS. 
Face-to-face communication with the lecturer is restricted to one contact session. It is logistically challenging to identify time slots in the time tables of all the students enrolled in the module and the contact session takes place outside class time. The students also have a one-hour project proposal session and a one-hour project presentation session in the lecturer's office. The LMS, email communication and access to a cellphone number allocated to the module play an important role in supporting effective communication. Furthermore, students' access to the lecturer at any time is vital, for example, during emergencies where students may be involved in an accident, a mugging or hijacking.

The students have to work on their project for at least 40 hours. These hours may include the preparation for the project. For example, students who develop a website and load it onto the World Wide Web do not need to work on site for the entire 40 hours. The project must require advanced knowledge and skills.

During the project proposal session, a possible project is identified and discussed. It is important that students are interested in their project. Students may choose a project from existing projects or may identify a new project. More than 400 campus-community partners are involved in the module annually. Campus-community partners also forward possible projects to the lecturer from which students may choose.

The lecturer contacts the campus-community partner during the project proposal session. A meeting is set up between the students and the contact person at the institution or community where they will do their fieldwork. The logistics for the successful completion of the project are also discussed. The logistics include, among other things, transportation to and from the site, as well as obtaining and managing the allocated funds for the project's successful completion. Students each receive R450 (\$40) and must use this money for transport and/or purchasing materials.

Regular feedback sessions are organised between the lecturer and the students. This may be done via face-to-face meetings or email. Students have to realise that they represent the University of Pretoria in the community. The relationship of trust between the lecturer and the students must be firmly established for their projects to be successfully completed. ${ }^{\text {vi }}$

While doing their fieldwork, students have to take at least five photographs of themselves interacting with the community or doing their project. Students must abide by ethical and privacy procedures associated with research and no photographs of a child in a shelter, children's home or patients may be taken.

A community representative has to assess the students' fieldwork on a prescribed form. The students also have to complete a log form that indicates how many hours they spent preparing for their project and how many hours they worked on site. These forms must be stamped and signed by the institution or community to verify participation. Where this is not possible, the contact details of a contact person, and the site's details, have to be filled in on the form. Where there is no community representative supervisor on site, for example, when computer training takes place on campus in the computer labs, a Community-based Project Module mentor may assess the students. Students who have already passed the module can be appointed as mentors.

After completing the project, students have to write a report in the form of a wiki on the LMS. As part of their reports, the students also develop a YouTube video. They deliver a presentation on their projects, including the project outcomes and lessons learnt during their projects. 


\section{MODULE OUTCOMES}

Service learning demonstrates to students that they can each make a difference. It increases their confidence as citizens. Although students' collective actions are not always successful, they learn from their mistakes by engaging in a continuous sequence of action and reflection. In their wiki reports, students reflect on the service-learning module as valuable, useful, and relevant to their future careers and self-development. The students become more engaged and acquire social knowledge and skills. Students who choose a project that requires analysis and problem-solving skills and situations where there is a personal connection with the community, find their projects more meaningful. They find the service learning meaningful when the service they provide actually meets an important need of the community.

Typical projects include teaching Mathematics and Physical Sciences, renovation projects, as well as animal- and zoo-related projects (Graph 1). Students who do their projects in their home towns usually feel that their involvement has made a significant impression on their community and they tend to show a higher degree of civic responsibility. Most of these students are the first in their families to study at a higher education institution. They are role models for the youths in their communities. By getting involved in their own communities, students show that they are willing to share their expertise, knowledge and skills with their communities.

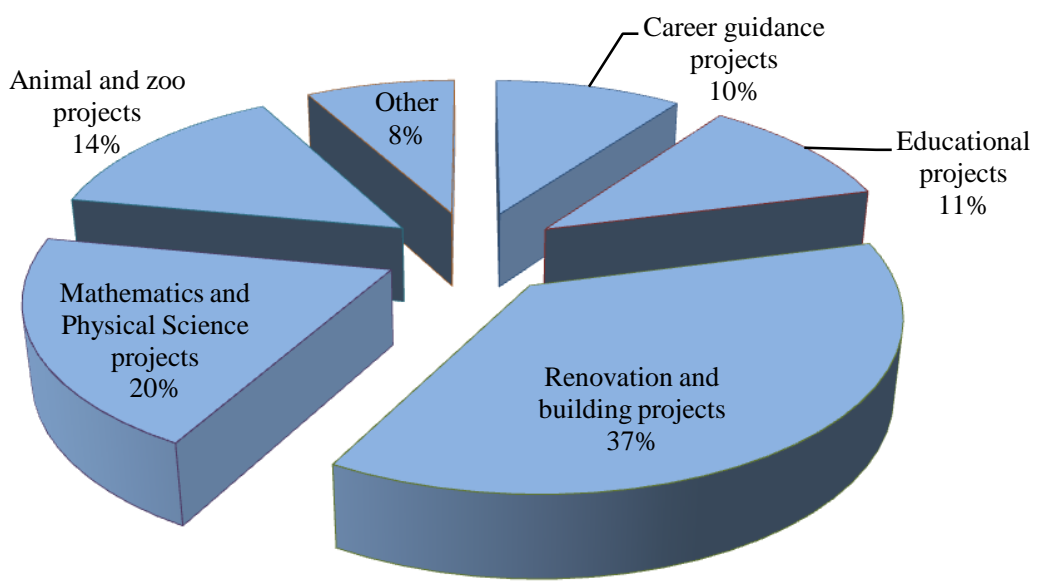

GRAPH 1

PROJECT DISTRIBUTION FOR 2014

The Community-based Project Module allows students to meaningfully engage in their local communities. After completing their projects, students understand the importance of leadership, teamwork and social skills. The survey of the 2005 to 2010 students was correlated with the survey of students enrolled in 2014 to determine their perception of what they have learnt in the module. According to the alumni and current students, project management skills and leadership skills were the most important skills they learnt during the execution of the project. However, the alumni and the current students had different views on time management. This may be attributed to alumni's time span in terms of the reflective evaluation of the skills learnt. The current students also indicated skills, like making a YouTube video, budgeting, building and renovation, as well as workshop practice skills, like welding, as required skills during the execution of the projects (Graph 2). 
This correlates with the findings of Mouton et al. ${ }^{\text {viii }}$ who report that, after the completion of a service learning module, students indicated that they had acquired leadership, project management and relationship skills (that would include group work). Moely et al. ${ }^{\text {ix }}$ found that the service experience required students to show initiative, creativity and flexibility in dealing with new or unexpected situations. This gave them the responsibility to determine the most effective way to accomplish their service goals and thus helped to develop their leadership skills.

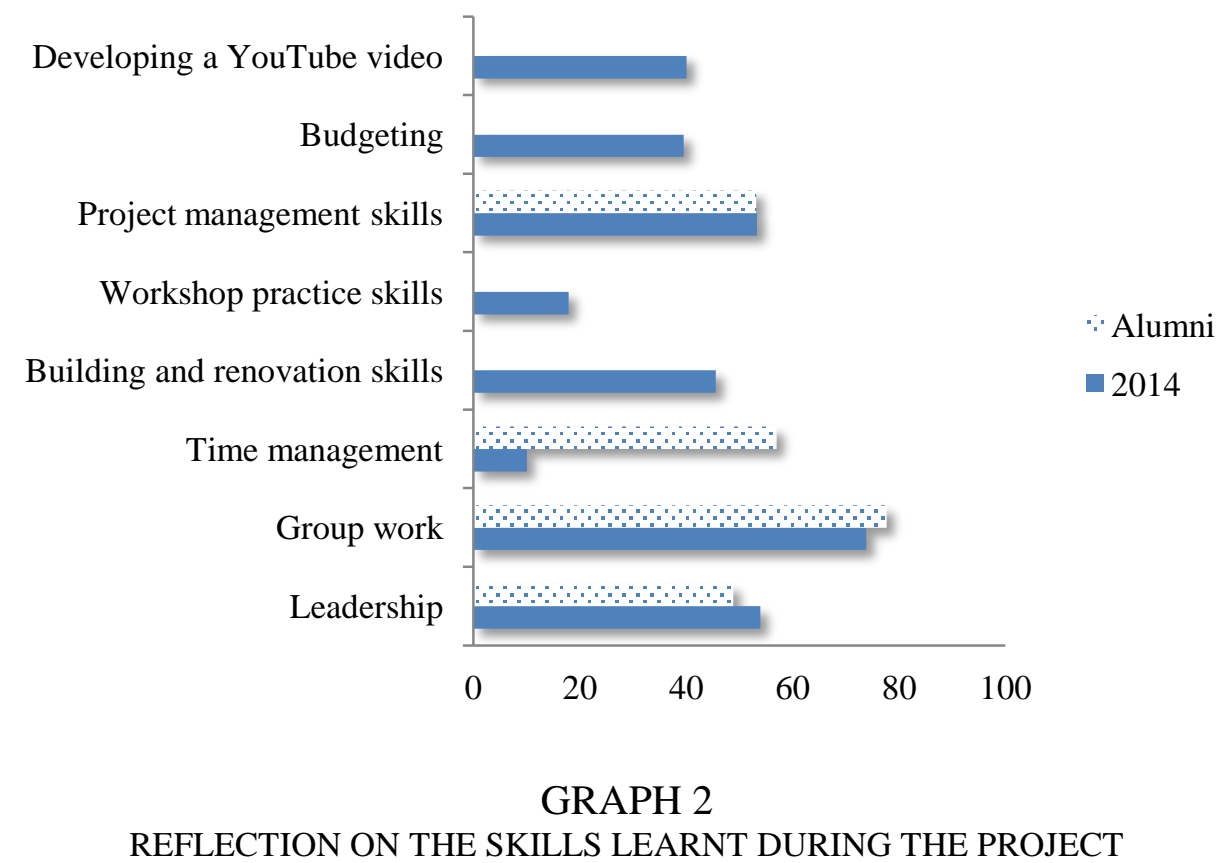

A significant percentage of the alumni $(76.84 \%)$ and $89.92 \%$ of the current students indicated that their experience during their fieldwork for the Community-based Project Module gave them an opportunity to understand their social responsibility (Graph 3).

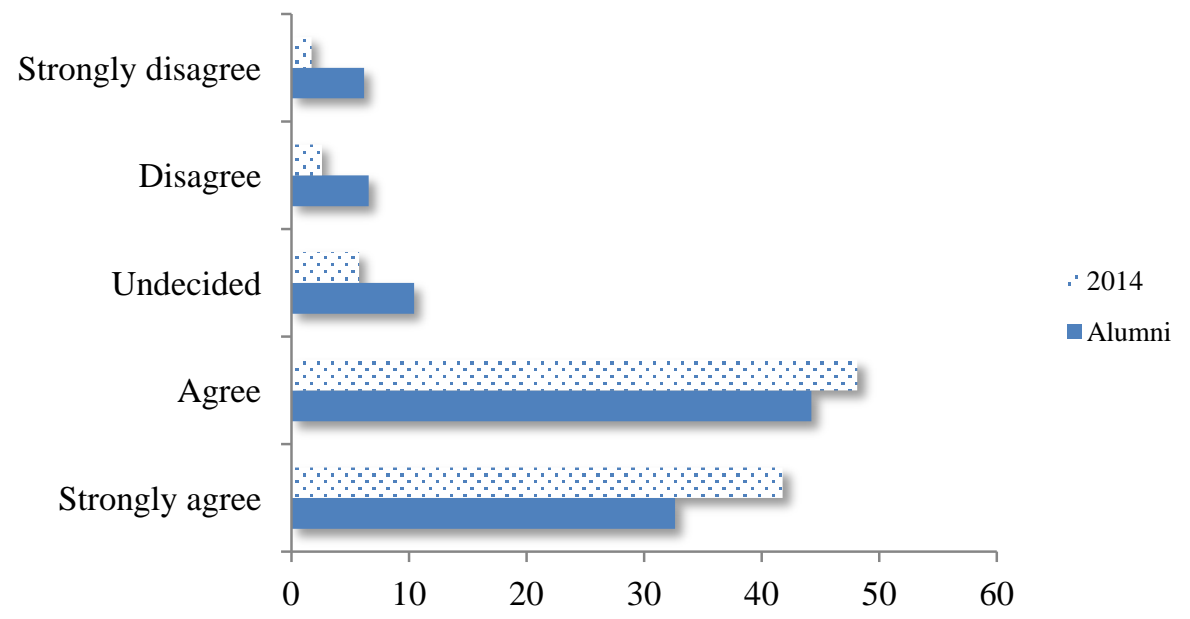

GRAPH 3

REFLECTION ON THE IMPORTANCE OF THE COMMUNITY-BASED PROJECT MODULE IN UNDERSTANDING SOCIAL RESPONSIBILITY 
In the survey of students enrolled in the module from 2005 to 2010, students indicated their involvement in a community project or outreach initiative since the completion of the undergraduate community module in relation to employment status. More than half of the alumni respondents $(54.83 \%)$ indicated that they became involved in a community outreach project after completing the Community-based Project Module. Of the alumni who are involved in community outreach projects, those who are currently employed reflect the highest employment status $(66.55 \%)$. The major reasons for non-involvement in a community outreach project included a demanding work schedule (39\%), private life priorities (20\%) and lack of opportunity (20\%). A significant percentage of the current students indicated that they will continue with a community outreach project again $(68.59 \%$ ) and $29.97 \%$ indicated that they might continue (Graph 4).

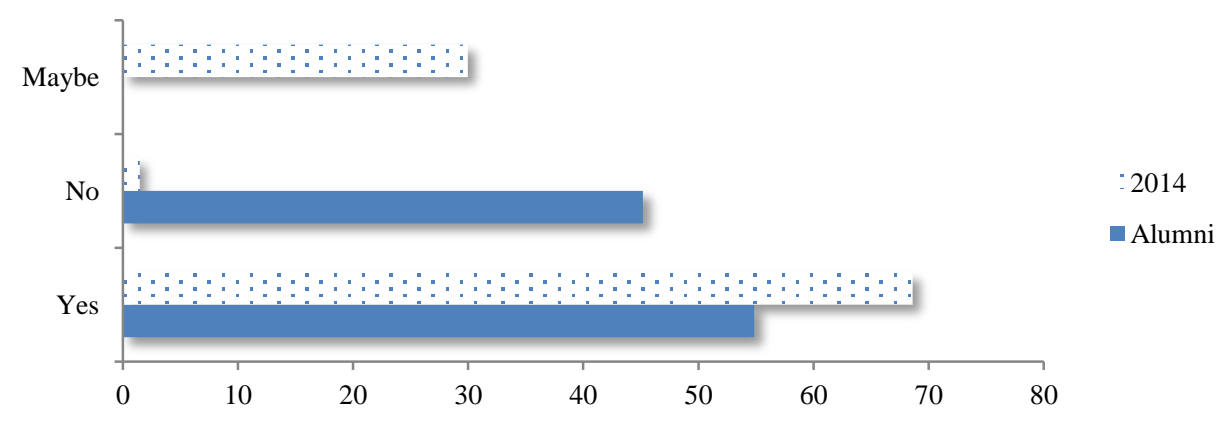

\author{
GRAPH 4 \\ ALUMNI STUDENTS' INVOLVEMENT IN A COMMUNITY SERVICE PROJECT OR OUTREACH \\ PROJECT SINCE THE COMPLETION OF THE UNDERGRADUATE MODULE AND CURRENT \\ STUDENTS' INDICATION OF POSSIBLE CONTINUATION IN COMMUNITY OUTREACH PROJECTS
}

\title{
LESSONS LEARNT
}

Various lessons have been learnt during the past years to streamline the module further. The lessons learnt contributed to the implementation of changes that were necessary to ensure the successful facilitation of the module. These changes also ensured the sustainability of the module and an increase in the successful completion of the projects within the communities.

For students, the module is very different from the other undergraduate modules in the curriculum. At the beginning of the academic year, students are unsure about the module's expectations. The students hail from different academic departments, which make it impossible to lecture during class hours. During the first few years after the module had been implemented, various contact sessions were scheduled. It soon became clear that students struggled to attend these sessions during the day, as it clashed with other classes. The lecturer changed the lecture venue from a normal venue to an auditorium that could seat more than 600 students. The contact sessions were presented after class hours. During these contact sessions, students are orientated with regard to the pedagogy of a service-learning module. The contact session forges a bond of commitment between the lecturer and the students. After the contact session, students demonstrate a greater eagerness to make a success of the module and their projects.

Students have to understand the rationale behind a service-learning module and its expectations. It is not always possible for the lecturer to organise forums and address the communities individually to explain the rationale of the module. Some of the projects are executed far from the campus and in other countries like Botswana, Namibia and Zimbabwe. 
In order to address the lack of communication, the lecturer establishes communication by telephone with a new community or at least with a manager, champion or organiser in the community where the students will do their projects, and indicates what is expected of both parties. Students are encouraged to keep their communities informed about their planned interaction with them through frequent communication.

To engage with communities where other departments of the University of Pretoria are already involved makes it easier to sustain a campus-community partnership. It is also possible to organise projects in collaboration with other faculties that address the community's various needs. This allows students to have a cross-faculty field experience. Cross-faculty projects include projects between engineering students and students from the Faculty of Veterinary Science at animal non-profit organisations like the International Primate Rescue Centre.

To identify specific projects on a site that may fall within the scope and criteria of the module, a student assistant of the Community-based Project Module may assist with the process. The student visits the site, identifies possible projects and takes photographs of these projects. The photographs are then loaded onto the announcement link of the LMS for students to view. ${ }^{\mathrm{x}}$

One of the challenges of the implementation of a service-learning module in South Africa is to ensure the safety of students. Students must be safe when they work in the communities. For their own safety, students may only work in a structured community setting. This includes non-profit organisations, as well as schools and pre-schools in disadvantaged communities. Students must always be aware of their immediate environment and that their safety is important. The use of official University transport does not only contribute to the increased awareness among students that they represent the University in the community, but also contributes to their safety. The University's vehicles are clearly branded, which increases visibility in the communities. The embedded tracking system in the vehicles and the accident and life insurance on the student's life makes University transport a safer option. This has cost implications for the module's budget, but these costs cannot be compared to the cost of safeguarding lives. The cost involved is deducted from the students' allocated funds for their projects.

During the contact session, a representative of the University's Department of Security Services presents a safety lecture to the students. Each group also receives a key ring with guidelines on what to do in an emergency, as well as the contact details of Security Services, the lecturer and the University of Pretoria's transport office.

One of the module's major challenges is to support all the students' travel arrangements. Not all the students have access to a vehicle and some cultures and religions do not allow students to travel in a mixed gender group. If students do not have a driver's license, a driver is allocated to the group.

The University's Department of Community Engagement informs the lecturer as soon as there is an emergency in the communities and if it is unsafe to go into a certain community. The students are immediately informed about these emergencies. Each student involved in projects located in unsafe areas also receives an email to indicate that they may not continue with their project for the time being. Bulk text messages are also immediately sent to all the students enrolled in the module. However, there is always a risk of students being exposed to unsafe circumstances. The lecturer's most important task is to ensure that students are aware of possible unsafe scenarios and how to react to them.

The University of Pretoria expects each student involved in a community engagement project to submit a National Child Protection Registration form. This verifies that, according to section 126 of the Children's Act, Act No. 38 of 2005, the student's name does not appear 
on the National Child Protection Register (Regulation 44). ${ }^{\mathrm{xi}}$ It is important that students are aware of the fact that they may not take photographs of the faces of any children in a shelter or children's home. Photographs of the children may not appear on YouTube, which will be available on the World Wide Web. This may have security implications for the child concerned. Students must also request permission from any individual to take photographs of him or her, as their faces will appear on YouTube.

Students at the University come from diverse backgrounds and are, to a certain extent, willing to try new experiences. To compel students to participate in specific projects could be detrimental to the module. When students identify their projects, needs in terms of logistic support, such as transport, accessibility and personal interest, should be taken into account. Most students are uncertain about the kind of projects in which they wish to participate. Therefore, a subtle guidance process is necessary to assist students to make decisions in this regard. Students should preferably work as part of a team in which they feel comfortable, but they may also work on their own.

The majority of communities are very positive about accommodating students' projects. These communities are eager to assist the students, where possible. It is important that the communities clearly understand the concepts, objectives, expectations and outcomes of the service the students will provide. According to the community's policy and prerequisites, this agreement between the community and the students is established in the form of a letter from the Community-based Project Module lecturer.

Financial support for the successful completion of projects allows students to work in less accessible areas and on more costly projects for longer periods. However, projects can still be executed without funding. Funding does not have to be the only prerogative for initiating a service-learning module at a higher educational institution. A good example of an e-service-learning project is Prof $\mathrm{Pi}$, an android application that links learners to volunteer tutors in order to get assistance with their mathematics homework ${ }^{\mathrm{xii}}$. Students only need to access the internet and are able to do the community work from home. ${ }^{\text {xiii }}$

The success of a service-learning module partly rests on the strength of the relationship between the Faculty and the community. ${ }^{\text {xiv }}$ This is established by identifying a particular contact person at each institution or non-governmental office where the students conduct their fieldwork. An empathetic and dedicated supervisor or contact person on site ensures the successful execution of a project and generates positive feedback from students on their experiences. A facilitator should ensure that students receive the assistance and support they need, but also that they have the opportunity to learn from their mistakes. ${ }^{\mathrm{xv}}$

The community, the students and the Faculty (the lecturer) must perceive that they will be able to make a worthwhile contribution to the initiative. Therefore, it is essential that there is common ground among all the partners, as well as transparent goals and objectives. ${ }^{\mathrm{xv}}$

\section{EXAMPLES OF SUCCESSFUL PROJECTS}

The following examples of campus-community partnerships may demonstrate how projects could be sustained. Due to the context of certain fields of study in the Faculty, undergraduate students are not allowed to work in their fields before they are qualified. For these students, other service-learning options had to be created.

Projects at primary and pre-primary schools

Various projects have been undertaken at public schools. This includes designing and building jungle gyms (Figure 1), painting games (Figure 2), renovating classrooms, 
developing websites for schools, and training staff members and learners on basic computer skills.

For example, a school in one of the townships adjacent to Pretoria indicated that it needed a library. Four successive groups created the library over a period of four years. One group cleared and cleaned the room, built cupboards and painted the room. The next group received donations of books, sorted them and created a reading section. The following group built a reception counter and the last group indexed the books electronically.

The success of the projects at the school can be accredited to a very passionate and positive principal and staff. The principal and staff were aware of what they could expect of the students and identified possible projects at the beginning of each academic year. A list of these projects was forwarded to the module's lecturer. Students could then choose projects from the provided list. The school was easily accessible and close to the campus. The students felt appreciated and experienced the school as accommodating and positive. ${ }^{\text {xii }}$

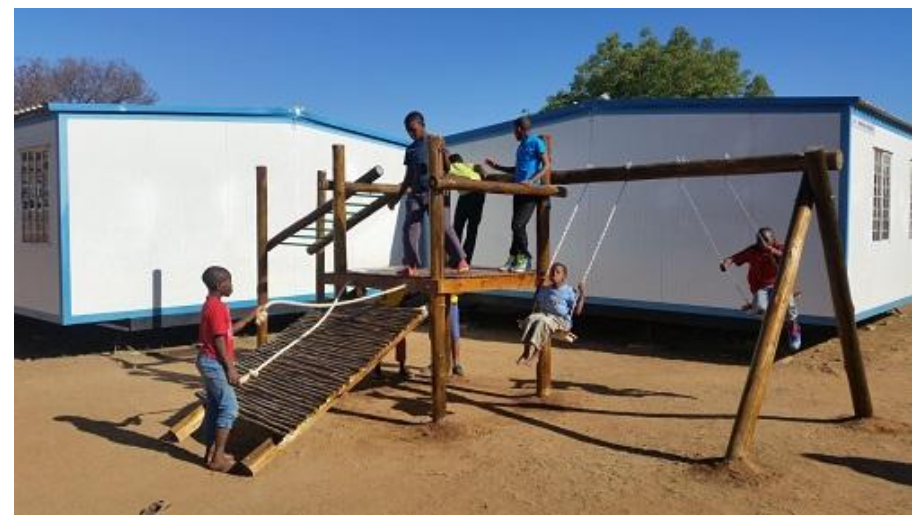

FIGURE 1

JUNGLE GYM FOR PRIMARY SCHOOLS

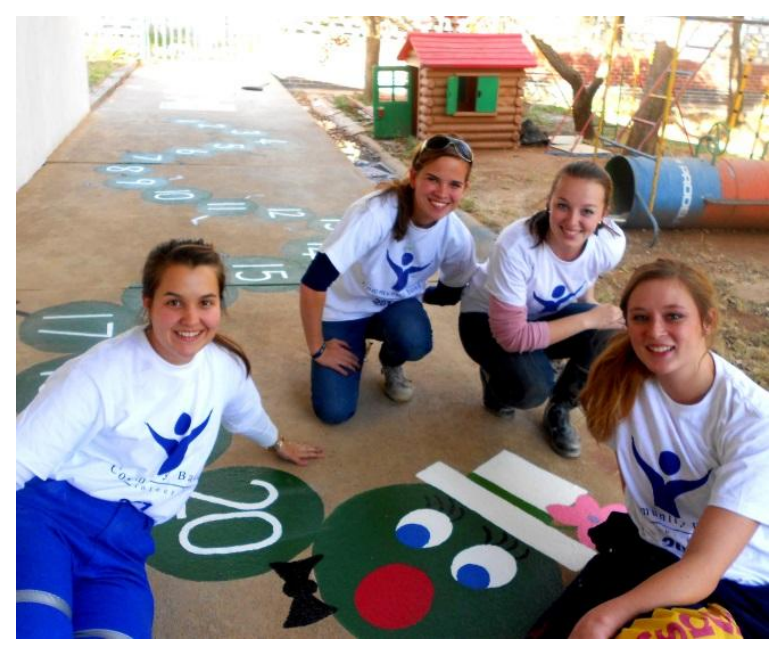

FIGURE 2

PAINTING GAMES FOR PRE-SCHOOLS

Projects where students assist with Mathematics and Physical Sciences

The level of Mathematics and Physical Sciences education in South Africa has been described as below international standards, as Mathematics and Physical Sciences education in South Africa has been placed last out of 148 countries, according to a World Economic Forum report. ${ }^{\text {xviii }}$ 
Students enrolled in the Community-based Project Module must have excellent Mathematics and Physical Sciences knowledge due to the minimum standards for enrolment in the Faculty. Many students prefer to return to their secondary schools and assist with these subjects (Figure 3). The schools are willing to accommodate the students and learners identify the students as possible role models. ${ }^{\text {xix }}$

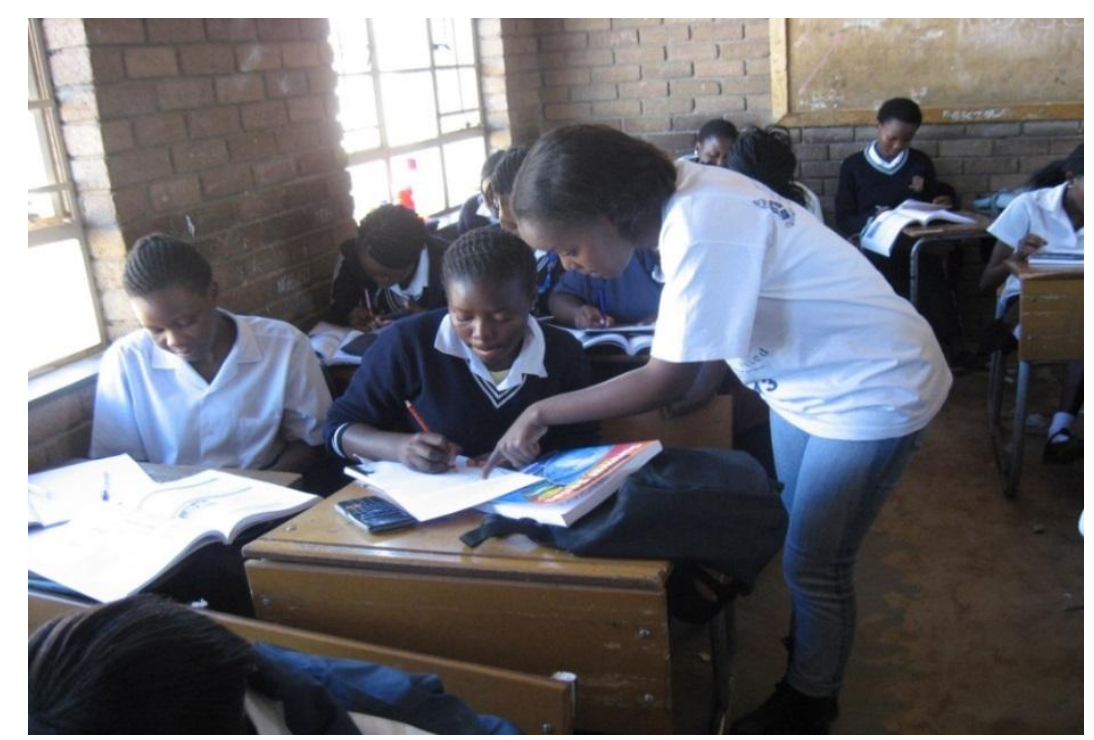

FIGURE 3

ASSISTING WITH MATHEMATICS AT SECONDARY SCHOOLS

Projects at animal shelters, sanctuaries and zoos

Students enjoy working at animal shelters, animal sanctuaries and zoos. Projects have been undertaken at various branches of the Society for the Prevention of Cruelty to Animals (SPCA), non-profit organisations like the Husky Romi Rescue and Wolf Sanctuary in Reitz in the Free State (Figure 4) and the Bester Birds and Animal Zoo in Pretoria.

The projects at the National Zoological Gardens of South Africa (NZG) in Pretoria are the most popular and more than 35 projects (between $5 \%$ and $8 \%$ of the projects) are annually executed at the NZG. The success of the campus-community partnership can be ascribed to a specific project coordinator at the NZG who identifies possible projects, together with the caretakers, for the students at the beginning of the academic year. Students then have the opportunity to select a project from this list. Most of the projects require technical and engineering skills. The opportunity to work in the NZG also makes these projects very popular in the Community-based Project Module. Projects have included designing and installing a shower for the elephants, hoist feeders for the giraffes and okapis, puzzle feeders for the apes and a hammock for the leopard (Figure 5). ${ }^{\mathrm{xx}}$ 


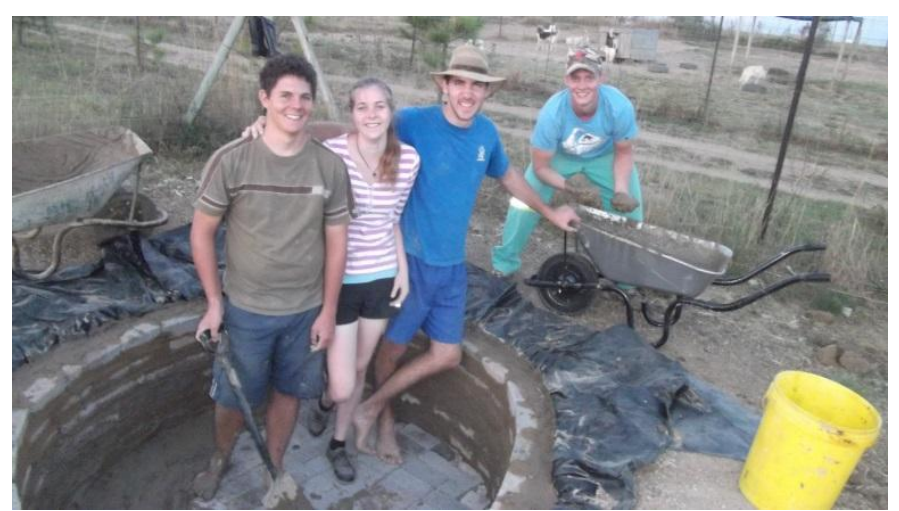

FIGURE 4

DIP BATHS FOR THE HUSKY ROMI RESCUE AND WOLF SANCTUARY

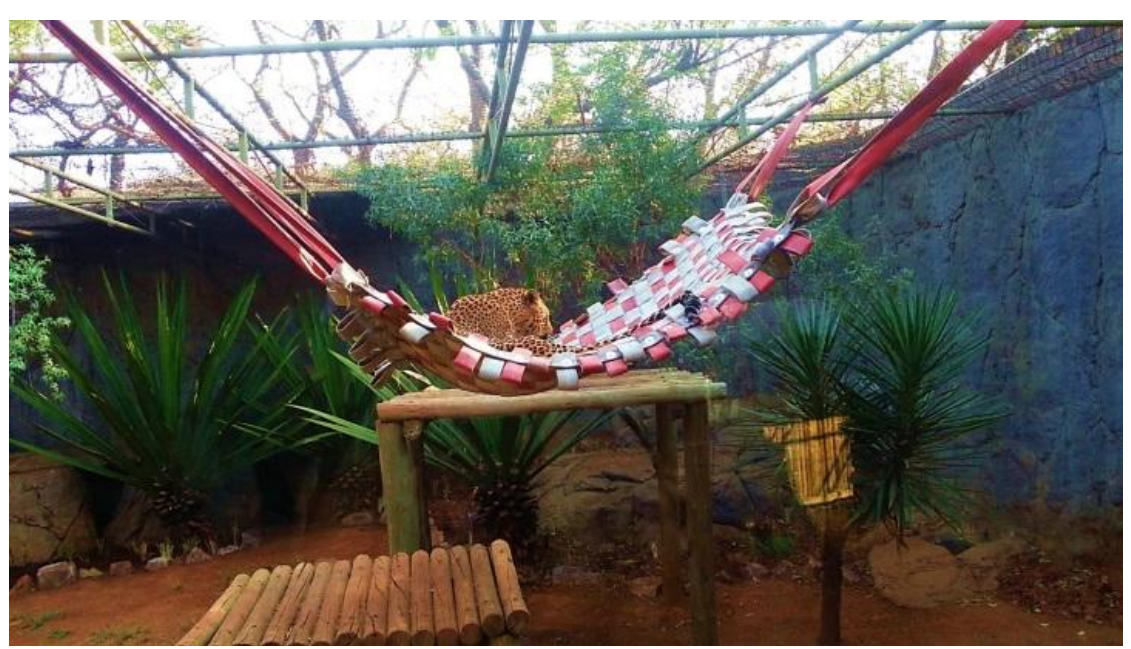

FIGURE 5

HAMMOCK FOR THE LEOPARD AT THE NATIONAL ZOOLOGICAL GARDENS OF SOUTH AFRICA

Projects using specialised information technology skills

Students enrolled in undergraduate courses already have advanced knowledge of information and communication technology and its applications. Many students find a project related to information technology an obvious choice. Projects range from basic computer literacy training for community members (Figure 6) to more advanced projects, such as the design and development of mobile applications or websites for non-profit organisations. The University of Pretoria annually replaces many computers. These computers are sometimes still usable for non-profit organisations or schools. Many students have the skills and knowledge to repair these computers, which can still be used by communities. Many nonprofit organisations and schools have a great need for conducive databases. These institutions lack the knowledge and workforce to create databases and populate them with the correct information. Some of the Community-based Project Module students enjoy designing a userfriendly database and providing assistance with the data capture. This is a popular project. 


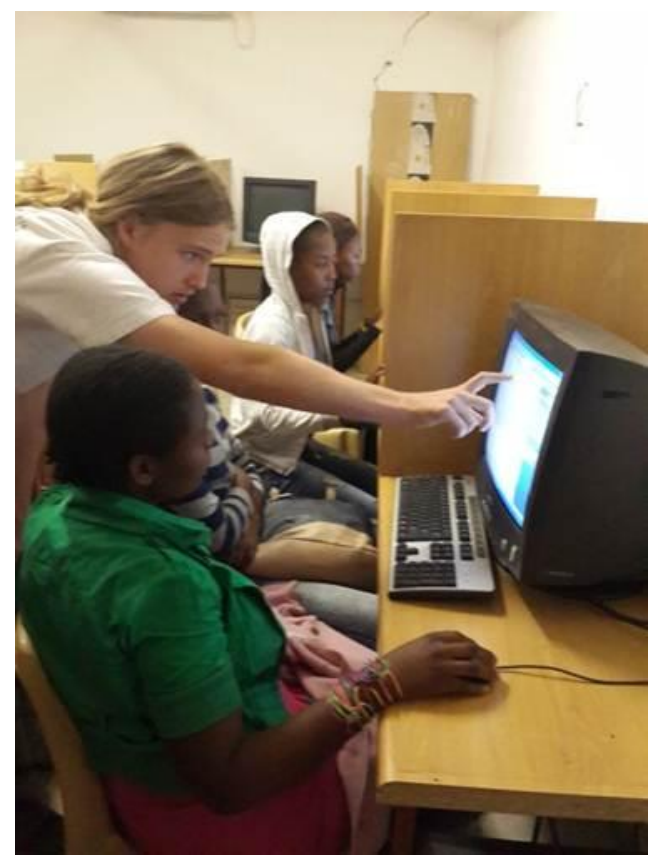

FIGURE 6

TEACHING BASIC COMPUTER SKILLS TO COMMUNITY MEMBERS

\section{CONCLUSION}

Various lessons were learnt during the implementation of the Community-based Project Module at the University of Pretoria. It is extremely challenging to facilitate the module with its large number of diverse students, various campus-community partners with different needs, as well as few available resources. The successful facilitation of the module depends highly on the partnerships between students, lecturers and community partners.

For most of the students, it is their first community outreach experience as service learning is not yet included in the curricula of schools. The students' intrinsic institutional responsibility of promoting the University of Pretoria's image in the community, dedication to their studies and commitment to achieving good results definitely influences their execution of and commitment to the projects.

Communities continue to accommodate the students because there is such an enormous need for assistance. These communities realise that all students will not necessarily deliver the same level of output, but they have the opportunity to transform the student into an engaged citizen or even to develop a lifelong relationship between a student and a particular cause or non-profit organisation. Service-learning projects and a deep commitment to community development are crucial for the success of service-learning projects.

\section{REFERENCES}

\footnotetext{
${ }^{\mathrm{i}}$ University of Pretoria. Annual review. 2013. http://www.up.ac.za/media/shared/520/ZP_Files/Publications/ar-2013-web.zp39682.pdf (accessed December, 07, 2014), 3.

ii University of Pretoria. Annual review. 2013. http://www.up.ac.za/media/shared/520/ZP_Files/Publications/ar-2013-web.zp39682.pdf (accessed December, 08, 2014), 4.

iii University of Pretoria, Faculty of Engineering, Built Environment and IT. http://www.up.ac.za/en/faculty-of-engineering-built-environment-it/article/30746/faculty-structure (accessed December, 07, 2014).
} 
${ }^{\text {iv }}$ M. Jordaan, M.C. Belino and C.R. Paredes. "International perspectives on service learning". In Convergence: philosophies and pedagogies for developing the next generation of humanitarian engineers and social entrepreneurs, edited by T.H. Collegde, 178-213. International Journal for Service Learning in Engineering: Humanitarian Engineering and Social Entrepreneurship (IJSLE: 2012).

${ }^{\vee}$ M. Jordaan. "Education of community engagement in higher education institutions in post-apartheid South Africa: the case of a community-based project module at the Faculty of Engineering, the Built Environment and Information Technology at the University of Pretoria". In Towards a sustainable ecology. 55 years after the Bandung Asian-African Conference 1955, edited by D. Khudori and Y. Kamino, (UB Press: Indonesia, 2012), 181.

${ }^{v i}$ Marketing, Advancement and Communication in Education. http://www.mace.org.za (accessed December, 08, 2014).

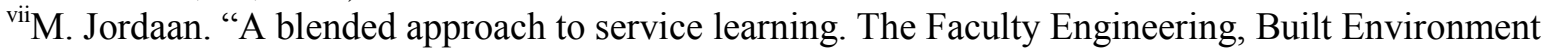
and Information Technology at the University of Pretoria". In Service learning in South Africa, edited by R. Osman and N. Petersen, (Oxford Press: Cape Town, 2013), 213, 214.

viii J. Mouton. and L. Wildschut. "Service learning in South Africa: lessons learnt through systematic evaluation". Acta Academica Supplementum 3 (2005), 116-150.

${ }^{i x}$ B.E. Moely, M. McFarland, D. Miron, S. Mercer and V. Ilustre. "Changes in college students' attitudes and intentions for civic involvement as a function of service-learning experience". Michigan Journal of Community Service Learning 9(1) (2002), 18-26.

${ }^{x}$ M. Jordaan. "A blended approach to service learning. The Faculty of Engineering, Built Environment and Information Technology at the University of Pretoria". In Service learning in South Africa, edited by R. Osman and N. Petersen, (Oxford Press: Cape Town, 2013), 221.

${ }^{x i}$ South Africa. 2006. Children's Act, No. 38 of 2005. Government Gazette No. 28944, June 19. http://www.justice.gov.za/legislation/acts/2005-038\%20childrensact.pdf (accessed August, 09, 2014).

${ }^{x i i}$ Nelson Mandela Metropolitan University. NMMU news and events. 20 October 2014. Partnership puts Prof Pi in your pocket. http://news.nmmu.ac.za/News/Partnership-puts-Prof-\%CE\%A0\%28Prof-pi\%29-in-your-Pocket (accessed December, 10, 2014).

${ }^{\text {xiii }}$ M. Jordaan. "A blended approach to service learning. The Faculty of Engineering, Built Environment and Information Technology at the University of Pretoria". In Service learning in South Africa, edited by R. Osman and N. Petersen, (Oxford Press: Cape Town, 2013), 221-224.

${ }^{x i v}$ B. Jacoby and Associates. "Service learning in higher education. Concepts and practices". (San Francisco: Jossey-Bass, 1996), 251.

${ }^{\mathrm{xv}} \mathrm{S} . \mathrm{H}$. Billig. "Unpacking what works in service-learning, promising research-based practices to improve student outcomes". NYLC Resource Centre. http://www.nylc.org/sites/nylc.org/files/files/323unpacking.pdf (accessed August, 08, 2014) (2007), 22.

${ }^{\mathrm{xvi}}$ Council on Higher Education. 2008. "Service learning in the disciplines - lessons from the field". http://www.che.ac.za/media_and_publications/research/service-learning-disciplines-lessons-field (accessed August, 08, 2014), 43.

${ }^{x v i i}$ M. Jordaan. "Ensuring sustainability in a community-based module". Acta Academica 44(1) (2012), 242.

xviii City Press. "SA scores lowest in maths, science education". 2 June 2014. http://www.citypress.co.za/news/sa-scores-lowest-maths-science-education (accessed December, $10,2014)$.

${ }^{\text {xix }}$ M. Jordaan. "A blended approach to service learning. The Faculty of Engineering, Built Environment and Information Technology at the University of Pretoria". In Service learning in South Africa, edited by R. Osman and N. Petersen, (Oxford Press: Cape Town, 2013), 225.

${ }^{\mathrm{xx}}$ M. Jordaan. "A blended approach to service learning. The Faculty of Engineering, Built Environment and Information Technology at the University of Pretoria". In Service learning in South Africa, edited by R. Osman and N. Petersen, (Oxford Press: Cape Town, 2013), 225-226. 